\title{
Corporate Responsibility towards the Protection and Management of the Environmental Land of Used Mine
}

\author{
Mahfud \\ mahfud.abdullah@unsyiah.ac.id \\ Universitas Syiahkuala, Indonesia
}

Submitted: 20 January 2021; Reviewed: 17 February 2021; Accepted: 27 April 2021

\begin{tabular}{|c|c|}
\hline Article's Information & Abstract \\
\hline $\begin{array}{l}\text { Keywords: Corporate; Responsibility; } \\
\text { Environmental; Mine. } \\
\text { DOI: } \\
\text { https://doi.org/10.25041/aelr.v2i1.2249 }\end{array}$ & $\begin{array}{l}\text { Humans exploiting their natural resources } \\
\text { must always be based on an environmental } \\
\text { approach. This is reasonable because } \\
\text { environmental problems are closely related to } \\
\text { population growth, the impact of which is the } \\
\text { high demand for natural resources. One of the } \\
\text { natural resources most widely used by humans } \\
\text { for various purposes is coal. The negative } \\
\text { impact of coal mining is to trigger } \\
\text { deforestation and exacerbate climate change. } \\
\text { This writing uses normative juridical research. } \\
\text { The approach used is the statutory approach. } \\
\text { Therefore, the management process of } \\
\text { exploring and exploiting every mining } \\
\text { material, especially coal, requires various } \\
\text { AMDAL mechanisms as part of } \\
\text { environmentally sound development } \\
\text { management. Provisions regarding mineral } \\
\text { and coal mining activities oblige mining } \\
\text { companies to carry out reclamation and post- } \\
\text { mining activities of the mining areas they } \\
\text { cultivate. The scope of the implementation of } \\
\text { reclamation activities starts from exploration, } \\
\text { land clearing, excavation of top and over- } \\
\text { borders, coal excavation, land arrangement, } \\
\text { revegetation, including nursery preparation, } \\
\text { and maintenance and evaluation of activity } \\
\text { results. Reclamation is carried out no later } \\
\text { than one month after there are no more mining }\end{array}$ \\
\hline
\end{tabular}


business activities on disturbed land.

Reclamation and post-mining activities are one of the obligations of mining business activities.

\section{A. Introduction}

The environment is one of the essential components of human life. Therefore, humans exploiting their natural resources must always be based on an environmental approach. ${ }^{1}$ This is reasonable because the natural resources needed have limitations in many ways, namely limitations regarding availability according to quantity and quality. ${ }^{2}$ This is where the fundamental role of the ruler can be a good manager in any policymaking that has a paradigm concept of thinking that cares about the environment. ${ }^{3}$ One of these policies was the issuance of Law Number 32 of 2009 concerning Environmental Protection and Management or Undang-Undang Perlindungan dan Pengelolaan Lingkungan Hidup (UU-PPLH) as evidence of environmental management by the authorities. ${ }^{4}$ Not only that, proper regulation will save the correlation between humans and the environment, whose benefits will also return to the community itself..$^{5}$

The emergence of environmental regulations followed by law enforcement policies as an environmental crime is the essence of efforts to avoid the emergence of environmental quality degradation itself. ${ }^{6}$ Degradation in the form of direct or indirect changes to its physical and/or biological characteristics results in the environment no longer functioning in supporting sustainable development. ${ }^{7}$ Even a tiny change of a factor in an ecosystem can affect living things in its environment. ${ }^{8}$ This is reasonable because environmental problems are closely related to demographic processes. Therefore, population growth has an impact on the environmental problem. ${ }^{9}$ The problem of population growth faced in almost all regions of Indonesia is due to the high demand for natural resources. ${ }^{10}$

One of the demands for natural resources for energy fulfillment for humans that continues to increase in population is coal. ${ }^{11}$ As a result, exploitation and exploration of

\footnotetext{
${ }^{1}$ RR DIAH NUGRAHENI SETYOWATI MISBAKHUL MUNIR, "KAJIAN REKLAMASI LAHAN PASCA TAMBANG DI JAMBI, BANGKA, DAN KALIMANTAN SELATAN,” Klorofil 1, no. 1 (2017), http://jurnal.uinsu.ac.id/index.php/klorofil/article/view/1233.

2 N. Zakiyyatul Mufidah and Miftachur R. Habibi, "KONSEP ECOCRACY SEBAGAI PERLINDUNGAN HUKUM LINGKUNGAN TERHADAP PELANGGARAN REKLAMASI PASKA PENAMBANGAN," Simposium Hukum Indonesia 1, no. 1 (June 12, 2019): 574-86, http://journal.trunojoyo.ac.id/shi.

${ }^{3}$ Untung Sri Hardjanto, Amiek Soemarmi Agnes Grace Aritonang*, "PENGELOLAAN LIMBAH DI PERUSAHAAN PULP PT. TOBA PULP LESTARI,TBK KABUPATEN TOBA SAMOSIR SUMATERA UTARA MENURUT UNDANGUNDANG NOMOR 32 TAHUN 2009 TENTANG PERLINDUNGAN DAN PENGELOLAAN LINGKUNGAN HIDUP," Diponegoro Law Journal, vol. 5 (Program Studi S1 Ilmu Hukum, Fakultas Hukum, Universitas Diponegoro, June 24, 2016), https://ejournal3.undip.ac.id/index.php/dlr/article/view/12224.

${ }^{4}$ Muhammad Yaasiin Raya and Irwansyah Irwansyah, "Analisis Kewajiban Deposito Sebagai Jaminan Reklamasi Dan Pascatambang," Papua Law Journal 1, no. 2 (October 25, 2018): 220-36, https://doi.org/10.31957/plj.v1i2.589.

${ }^{5}$ Zulfadhly Sanusi, "Tantangan Pemulihan Lingkungan Di Masa Pandemi Covid-19: Antara Idealita Dan Realita," PETITUM 8, no. 2 (October 22, 2020): 114-30, https://doi.org/10.36090/jh.v8i2.808.

${ }^{6}$ Bruce Mitchell, Pengelolaan Sumber Daya dan Lingkungan, Edisi Pertama, Gadjah Mada University Press, Yogyakarta 2000, hlm 5.

${ }^{7}$ Takdir Rahmadi, Hukum Lingkungan di Indonesia, PT. Raja Grafindo Persada, Jakarta, 2012, hlm 223.

${ }^{8}$ Mulyanto, Ilmu Lingkungan, Graha Ilmu, Yogyakarta, 2007, hlm 1.

${ }^{9}$ Pramudya Sunu, Melindungi Lingkungan dengan Menerapkan ISO 14001, PT Gramedia Widiasarana Indonesia, Jakarta, 2001, hlm 7.

10 Roni Sulistyanto Luhukay, "TANGGUNG JAWAB PT FREEPORT INDONESIA TERHADAP PENANGANAN KERUSAKAN LINGKUNGAN AKIBAT PERTAMBANGAN DI KABUPATEN MIMIKA PAPUA," LEX ET SOCIETATIS, vol. 4, March 17, 2016, https://ejournal.unsrat.ac.id/index.php/lexetsocietatis/article/view/11533.

${ }^{11}$ Restu Juniah Suhardiman Gumanti, "Kajian Implementasi Kegiatan Tanggung Jawab Sosial Perusahaan Pertambangan (Corporate Social Responsibility) Terhadap Pemberdayaan Masyarakat Dan Lingkungan," Jurnal Empirika 1, no. 2 (November 22, 2016): 111-26, https://doi.org/10.47753/JE.V1I2.18.
} 
natural resources in mining constantly threaten environmental sustainability. ${ }^{12}$ The negative impact of coal mining is to trigger deforestation and exacerbate climate change. Coal is very fast in causing great danger to the population of this world. Its harmful effects cannot compensate for the benefits it brings. So leaving the use of coal is the only way not to damage the environmental ecosystem. Therefore, the management process of exploring and exploiting every mining material, especially coal, requires various Environmental Impact Analysis or Analisis Dampak Lingkungan (AMDAL) mechanisms as part of environmentally sound development management. The environmental management policy is a conscious effort and plans to use and manage resources wisely in sustainable development to improve the quality of life. ${ }^{13}$

The spirit of environmentally sustainable management is also mandated in the definition of mining in Article 1 number 1 of Law Number 4 of 2009 concerning Mineral and Coal Mining: which states, "Part or all stages of activities in the context of research, management and control of minerals or coal which have general investigations, exploration, feasibility studies, construction, mining, processing and refining, transportation and sales, as well as post-mining activities". ${ }^{14}$ The mining definition clearly states that mining activities involve not only exploitation issues but also post-mining activities such as reclamation activities. Reclamation is carried out to restore ex-mining land to a better condition. ${ }^{15}$

The provisions concerning reclamation are regulated in detail in Article 96 letter c of Law Number 4 of 2009 concerning Mineral and Coal Mining. This article states that the holders of Mining Business Permits or Izin Usaha Pertambangan (IUP) and Special Mining Business Permits or Izin Usaha Pertambangan Khusus (IUPKs) are required to carry out management and monitoring of the mining environment, including reclamation and postmining activities. Namun dalam perkembanggan banyak dari kegiatan eplorasi maupun ekploitasi pertambangan batubara menimbulkan dampak lingkungan yang sangat parah bukan saja secara ekositem tetpai juga dampak sosial. This is the case with Samarinda City, one of the cities with the most coal mining companies. It is undeniable that coal mining in Samarinda City has resulted in erosion and silting of the river flow, which has triggered more frequent flooding. It is believed that the floods that frequently hit several areas in Samarinda City are a direct impact of environmental damage to both minings. Previously, floods occurred in the annual cycle in Kota Samarinda, but now in one year, there can be four cases of significant floods.

Coal mining also causes pollution of agricultural lands and residents' ponds. The East Kalimantan Mining Advocacy Network or Jaringan Advokasi Tambak (JATAM) in Samarinda revealed data that due to rampant coal mining activities has reduced the quality of the environment in Samarinda, especially those that affect the river, swamp, and lake water springs, and water. With a decrease in environmental quality as described above, reclamation or restoration of the environment to its original condition is a must, especially reclamation that must be carried out at ex-mining locations. This is done to reduce the impact of even more significant environmental damage.

Based on the problems that the authors put forward above, some of the problems in this paper can be described, namely how the responsibility of the coal mining company to

\footnotetext{
12 Diemas Adhitya Pratama Suprijadi, "KAJIAN HUKUM PEMULIHAN PENCEMARAN LINGKUNGAN DAERAH BEKAS PERTAMBANGAN MENURUT UNDANG-UNDANG NOMOR 32 TAHUN 2009 TENTANG PERLINDUNGAN DAN PENGELOLAAN LINGKUNGAN HIDUP,” LEX ET SOCIETATIS, vol. 7, July 30, 2019, http://pontianak.tribunnews.com/2015/09/10/9-dampak-.

${ }^{13}$ Harun M. Husein, Lingkungan Hidup Masalah Pengelolaan dan Penegakan Hukumnya, Bumi Aksara, Jakarta, 1992, hlm 50.

${ }^{14}$ See Article 1 number 1 Law Number 4, Year 2009 concerning Mineral and Coal Mining.

15 Ade Lutfi Prayogo, "Tanggung Jawab Pelaku Usaha Pertambangan Rakyat Dalam Reklamasi Gumuk Setelah Kegiatan Tambang,” Lentera Hukum 5, no. 3 (2018): 2621-3710, https://doi.org/10.19184/ejlh.v5i3.8201.
} 
protect and manage the environment and the obligation of a coal mining mineral company to restore ex-mining land.

\section{B. Discussion}

Law No. 4 of 2009 concerning Mineral and Coal Mining requires mining companies to carry out reclamation and post-mining activities of the mining areas they cultivate. ${ }^{16}$ To have a coercive effect for mining entrepreneurs to carry out reclamation, these entrepreneurs are required to submit a sum of money as reclamation collateral, which must be placed before the company carries out production operations, as regulated in Article 35 paragraph (4) of the Regulation of the Minister of Energy and Mineral Resources Number 18 of $2008 .{ }^{17}$ In the implementing regulations based on the provisions of Article 15 of the Regulation of the Minister of Energy and Mineral Resources Number 18 of 2008, the implementation of reclamation must be carried out on land disturbed by mining. The land is either in the ex-mine or on the land outside the ex-mine, which is no longer used. Land outside ex-mining includes: (1) landfill; (2) stockpile of raw materials/production; (3) Road transportation; factories/processing/refining installations; (5) Offices and housing; and/or (6) Ports/jetty. ${ }^{18}$

The scope of the implementation of reclamation activities starts from exploration, clearing the field (land clearing), excavation of top and overland, coal excavation, land arrangement, revegetation including nursery preparation, and maintenance and evaluation of activity results. Reclamation is carried out no later than one month after there are no more mining business activities on disturbed land. After implementing the reclamation implementation report every one year to the governor. Reports are prepared based on reports on the implementation of reclamation activities in Appendix III of the Regulation of the Minister of Energy and Mineral Resources Number 18 of 2008. ${ }^{19}$

Based on the provisions in Article 96 letter (c) of Law Number 4 of 2009 concerning Mineral and Coal Mining, the holders of Mining Business Permits or Izin Usaha Pertambangan (IUP) and Special Mining Business Permits or Izin Usaha Pertambangan Khusus (IUPK) are required to carry out management and monitoring of the mining environment, including reclamation and mining activities. ${ }^{20}$ Mining companies that do not fulfill these obligations may be subject to sanctions with the revocation of Mining Business Permits (IUP) or Special Mining Business Permits (IUPK), this is based on Article 117 letter b of Law Number 4 of 2009 concerning Mineral and Coal Mining regarding the expiration of Business Permits. Mining (IUP) or Special Mining Business Permit (IUPK).

Article 6 describes the existence of 21 powers for the central government, article 7 of Law no. 4 of 2009 describes the existence of 14 fourteen authorities for the provincial government. Finally, article 8 of Law no. 4 of 2009 describes twelve authorities for district or city governments. The various powers related to reclamation are as follows:

1) Determination of reclamation and post-mining policies.

Reclamation and post-mining activities are one of the obligations of mining business activities. Before carrying out these reclamation and post-mining activities, a mining

\footnotetext{
${ }^{16}$ Asti Amelia Novita, "Collaborative Governance Dan Pengelolaan Lingkungan Hidup Di Kawasan Pertambangan,” Jurnal Ilmiah Administrasi Publik 4, no. 1 (April 1, 2018): 27-35, https://doi.org/10.21776/ub.jiap.2019.004.01.4.

${ }^{17}$ See the provisions of Article 35 paragraph (4) of the Regulation of the Minister of Energy and Mineral Resources Number 18 of 2008

${ }^{18}$ Article 15 Regulation of the Minister of Energy and Mineral Resources Number 18 of 2008

${ }^{19}$ Burhanudin JP, Tinjauan Kegiatan Reklamasi Lahan Bekas Tambang di PT Bukit Asam (Persero) Tbk Bagi Pembelajaran Diklat Kehutanan, http://pusdiklat.dephut.go.id.

${ }^{20}$ Nuzul Qur'aini Mardiya, "PENGATURAN PERTANGGUNGJAWABAN KORPORASI DALAM TINDAK PIDANA LINGKUNGAN HIDUP / THE REGULATION OF CORPORATE LIABILITY IN ENVIRONMENTAL CRIMINAL ACT," Jurnal Hukum Dan Peradilan 7, no. 3 (December 18, 2018): 483, https://doi.org/10.25216/jhp.7.3.2018.483-502.
} 
business license is required to be issued by the central, provincial, or district/city governments under their respective authorities. The authority of the central government is stated in Article 6 of Law No.4 of 2009:

a. Establishment of national policies;

b. Establishment laws and regulations;

c. Establishment of national standards, guidelines, and criteria;

d. Application of the national mineral and coal mining licensing system;

e. Determination of mining areas after coordinating with the Regional Government and the Indonesian Parliament;

f. Granting of Exploration IUP and Production Operation IUP;

g. Evaluating Production Operation IUPs, which are issued by local governments, which have caused environmental damage and which do not apply sound mining principles;

h. Guidance and supervision of the implementation of mineral and coal mining management carried out by regional governments;

i. Guidance and supervision of the preparation of regional regulations in the mining sector.

Meanwhile, the authority of the provincial and district/city governments is in the form of stipulating policies in the making of regional laws and regulations, guidance, and supervision. (Article 7 and Article 8 of Law No.4 of 2009). Determination of policies related to post-mining reclamation activities is contained in government regulation. Based on Article 101 of Law no. 4 of 2009, the Government Regulation no. 78 of 2010 concerning reclamation and post-mining. In Government Regulation no. 78/2010, the principles of reclamation and post-mining are contained in Article 2 (1) and paragraph (2), which states that:

1) The holder of an Exploration IUP and an Exploration IUP is obliged to carry out reclamation.

2) Holders of Production Operation IUP and Production Operation IUPK are obliged to carry out reclamation and post-mining activities.

The implementation of reclamation by holders of IUP Exploration and IUPK Exploration must comply with the protection and management principles of the mining environment and occupational safety and health. The principle of protection and management of the mining environment has criteria that must be implemented in the form of:

a. Protection of the quality of surface water, groundwater, sea water, and soil and air based on quality standards or environmental damage standard criteria under the provisions of statutory regulations;

b. Protection and restoration of biodiversity;

c. Guarantee of the stability and safety of overburden, tailings ponds, ex-mining areas, and other artificial structures;

d. Utilization of ex-mining land according to its allotment;

e. Pay attention to local social and cultural values; and

f. Protection of the quantity of groundwater following statutory provisions.

The principles of occupational safety and health include:

a. Safety protection for every worker or laborer.

b. Protection of every laborer from occupational diseases. ${ }^{21}$ 
Mining activity permits are divided into three types, namely Mining Business Permits (IUP) as regulated in Article 8 of Government Regulation No. 23/2010 concerning the Implementation of Mineral and Coal Mining Business Activities carried out utilizing a regional application. Application for the area means that every party, business entity, cooperative or individual wishing to have a Mining Business License (IUP) must submit an application to the Minister, Governor, Regent, or Mayor under their authority. Special Mining Business Permits (IUPK) are granted to carry out mining concessions in the Special Mining Business Permit Area or Wilayah Izin Usaha Pertambangan Khusus (WIUPK), which is from the National Mining Area or Wilayah Pertambangan Nasional (WPN). ${ }^{22}$ Community Mining Business License (IPR). For reclamation and post-mining activities to be carried out and meet the success criteria, several stages must be passed, starting from the application for a permit to manage the reclamation plan and post-mining plan, approval of the reclamation plan, and post-mining plan, to changes to the reclamation plan and post-mining plan. These stages are regulated in Government Regulation No. 78/2010, which must first be through a permit from the minister, governor, regent/mayor.

In addition, providing a reclamation guarantee fund and a post-mining guarantee fund is one of the obligations that must be made for IUP and IUPK holders. The government establishes a policy for each IUP and IUPK holder to place a reclamation guarantee and a post-mining guarantee. This guarantee is needed as a manifestation of the seriousness of each IUP and IUPK holder to restore ex-mining land and land outside ex-mining according to the allocation agreed upon by the stakeholders in the context of sustainable development.

Post mining guarantees are determined according to the post-mining plan. This guarantee is placed annually in the form of a time deposit at a state bank. The amount of postmining guarantee is calculated based on cost:

a. Direct costs include:

1. Demolition of buildings and supporting facilities that are no longer in use;

2. Reclamation of ex-mine sites, processing, and refining facilities, and supporting facilities;

3. Handling of Hazardous and Toxic Materials and waste;

4. Maintenance and preservation

5. Monitoring; and

6. Social, economic, and cultural aspects.

b. Indirect costs include:

1. Mobilization and demobilization;

2. Activity planning;

3. Administration and benefits of a third party as a mine closure contractor; and

4. Supervision. $^{23}$

The time deposit is valid until all post-mining activities are declared complete by the governor. Disbursement of time deposits and interest is carried out after post-mining activities are carried out following the stages of completion of the work that has been carried out based on the post-mining plan approved by the governor. ${ }^{24}$ The placement of post-mining guarantees by the company does not eliminate the company's obligation to carry out post-

\footnotetext{
Nandang Sudrajat, Teori dan Praktik Pertambangan Indonesia Menurut Hukum, Pustaka Yustisia, Yogyakarta, 2010, hlm 79. Article 35 paragraph (4) Regulation of the Minister of Energy and Mineral Resources Number 18 of 2008.

Article 37 Regulation of the Minister of Energy and Mineral Resources Number 18 of 2008.
} 
mining activities. ${ }^{25}$ If the company lacks funds to complete post-mining activities from the stipulated guarantee, it remains the company's responsibility.

Reclamation must be carried out on land disturbed by mining. The land is either in the ex-mine or on the land outside the ex-mine, which is no longer used. The land outside the exmining includes: ${ }^{26}$

(1) Cover soil stockpile;

(2) Hoard of raw materials/production;

(3) Transportation Road

(4) Processing/refining plant/installation;

(5) Offices and housing; and/or

(6) Harbor/pier

The scope of the implementation of reclamation activities starts from exploration, clearing the field (land clearing), excavation of top and overland, coal excavation, land arrangement, revegetation including nursery preparation, and maintenance and evaluation of activity results. ${ }^{27}$ Reclamation is carried out no later than one month after there are no more mining business activities on the disturbed land. ${ }^{28}$ After implementing the reclamation implementation report every year to the governor, reports are prepared based on the preparation of reports on the implementation of reclamation activities in Appendix III of the Regulation of the Minister of Energy and Mineral Resources Number 18 of 2008.

\section{Conclusion}

Law No. 4 of 2009 concerning Mineral and Coal Mining requires mining companies to carry out reclamation and post-mining activities for the mining areas that they operate. To have a coercive effect on mining entrepreneurs to carry out reclamation, these entrepreneurs are required to submit a sum of money as reclamation collateral, which must be placed before the company carries out production operations. The scope of the implementation of reclamation activities starts from exploration, land clearing, excavation of top and over-borders, coal excavation, land arrangement, revegetation, including nursery preparation, and maintenance and evaluation of activity results.

\section{A. Book}

\section{Bibiliography}

Hamzah, Andi. 1993. Sistem Pidana dan Pemidanaan Indonesia, Jakarta: Pradnya Paramita.

Husein, Harun M. 1992.Lingkungan Hidup Masalah Pengelolaan dan Penegakan Hukumnya, Jakarta: Bumi Aksara.

Mitchell, Bruce. 1991. Pengelolaan Sumber Daya dan Lingkungan, Edisi Pertama, $\quad$ Yogyakarta: Gadjah Mada University Press.

Mulyanto. 2007. Ilmu Lingkungan, Yogyakarta: Graha Ilmu.

Otto Soemarwoto. 1999. Analisis Mengenai Dampak Lingkungan, Yogyakarta: Gadjah Mada University Press, Cetakan Kedelapan.

\footnotetext{
25 Ulfia Hasanah, "PERLINDUNGAN HUKUM TERHADAP HAK-HAK MASYARAKAT DIDAERAH AREA PERTAMBANGAN," Jurnal Ilmu Hukum, vol. 6, April 11, 2017, https://doi.org/10.30652/JIH.V6I1.4033.

${ }^{26}$ Leonardo Siregar, "Penerapan Asas Pencemar Membayar Dalam Perkara Perdata Lingkungan Hidup (Studi Putusan Pengadilan Tinggi Riau Nomor 79/Pdt./2014/PTR) ,"Jurnal Mercatoria 13, no. 2 (December 28, 2020): 2541-5913, https://doi.org/10.31289/mercatoria.v13i1.3964.

27 Zulkifli Zam Zam and I Made Putrawan, "EVALUASI KEBIJAKAN PENGELOLAAN LINGKUNGAN PERTAMBANGAN DI PULAU OBI PROVINSI MALUKU UTARA," Jurnal Ilmiah Pendidikan Lingkungan Dan Pembangunan 21, no. 02 (September 29, 2020): 58-68, https://doi.org/10.21009/plpb.212.05.

28 Achmad Haris Januari, "SISTEM PEMBANGUNAN BERKELANJUTAN TERHADAP TATA KELOLA PERTAMBANGAN," Jurnal Hukum Dan Bisnis (Selisik) , vol. 1, 2015, https://doi.org/10.35814/SELISIK.V1I2.631.
} 
Pramudya Sunu. 2001. Melindungi Lingkungan dengan Menerapkan ISO 14001, Jakarta: PT Gramedia Widiasarana Indonesia.

Rahmadi, Takdir. 2012. Hukum Lingkungan di Indonesia, Jakarta: PT. Raja Grafindo Persada.

Sudrajat, Nandang. 2010. Teori dan Praktik Pertambangan Indonesia Menurut Hukum, Yogyakarta: Pustaka Yustisia.

Starke, J. G. 2004. Pengantar Hukum Internasional 1, Jakarta: Sinar Grafika.

\section{B. Journal}

Agnes Grace Aritonang*, Untung Sri Hardjanto, Amiek Soemarmi. "PENGELOLAAN LIMBAH DI PERUSAHAAN PULP PT. TOBA PULP LESTARI,TBK KABUPATEN TOBA SAMOSIR SUMATERA UTARA MENURUT UNDANG-UNDANG NOMOR 32 TAHUN 2009 TENTANG PERLINDUNGAN DAN PENGELOLAAN LINGKUNGAN HIDUP.” Diponegoro Law Journal. Vol. 5. Program Studi S1 Ilmu Hukum, Fakultas Hukum, Universitas Diponegoro, June 24, 2016. https://ejournal3.undip.ac.id/index.php/dlr/article/view/12224.

Amelia Novita, Asti. "Collaborative Governance Dan Pengelolaan Lingkungan Hidup Di Kawasan Pertambangan." Jurnal Ilmiah Administrasi Publik 4, no. 1 (April 1, 2018): 27-35. https://doi.org/10.21776/ub.jiap.2019.004.01.4.

Haris Januari, Achmad. "SISTEM PEMBANGUNAN BERKELANJUTAN TERHADAP TATA KELOLA PERTAMBANGAN." Jurnal Hukum Dan Bisnis (Selisik) . Vol. 1, 2015. https://doi.org/10.35814/SELISIK.V1I2.631.

Hasanah, Ulfia. "PERLINDUNGAN HUKUM TERHADAP HAK-HAK MASYARAKAT DIDAERAH AREA PERTAMBANGAN." Jurnal Ilmu Hukum. Vol. 6, April 11, 2017. https://doi.org/10.30652/JIH.V6I1.4033.

Luhukay, Roni Sulistyanto. "TANGGUNG JAWAB PT FREEPORT INDONESIA TERHADAP PENANGANAN KERUSAKAN LINGKUNGAN AKIBAT PERTAMBANGAN DI KABUPATEN MIMIKA PAPUA." LEX ET SOCIETATIS. Vol. 4, March 17, 2016. https://ejournal.unsrat.ac.id/index.php/lexetsocietatis/article/view/11533.

Mardiya, Nuzul Qur'aini. "PENGATURAN PERTANGGUNGJAWABAN KORPORASI DALAM TINDAK PIDANA LINGKUNGAN HIDUP / THE REGULATION OF CORPORATE LIABILITY IN ENVIRONMENTAL CRIMINAL ACT." Jurnal Hukum Dan Peradilan 7, no. 3 (December 18, 2018): 483. https://doi.org/10.25216/jhp.7.3.2018.483-502.

MISBAKHUL MUNIR, RR DIAH NUGRAHENI SETYOWATI. "KAJIAN REKLAMASI LAHAN PASCA TAMBANG DI JAMBI, BANGKA, DAN KALIMANTAN SELATAN.” Klorofil 1, no. 1 (2017). http://jurnal.uinsu.ac.id/index.php/klorofil/article/view/1233.

Mufidah, N. Zakiyyatul, and Miftachur R. Habibi. "KONSEP ECOCRACY SEBAGAI PERLINDUNGAN HUKUM LINGKUNGAN TERHADAP PELANGGARAN REKLAMASI PASKA PENAMBANGAN." Simposium Hukum Indonesia 1, no. 1 (June 12, 2019): 574-86. http://journal.trunojoyo.ac.id/shi.

Prayogo, Ade Lutfi. "Tanggung Jawab Pelaku Usaha Pertambangan Rakyat Dalam Reklamasi Gumuk Setelah Kegiatan Tambang." Lentera Hukum 5, no. 3 (2018): 2621-3710. https://doi.org/10.19184/ejlh.v5i3.8201.

Raya, Muhammad Yaasiin, and Irwansyah Irwansyah. "Analisis Kewajiban Deposito Sebagai Jaminan Reklamasi Dan Pascatambang." Papua Law Journal 1, no. 2 (October 25, 2018): 220-36. https://doi.org/10.31957/plj.v1i2.589.

Sanusi, Zulfadhly. "Tantangan Pemulihan Lingkungan Di Masa Pandemi Covid-19: Antara Idealita Dan Realita." PETITUM 8, no. 2 (October 22, 2020): 114-30. https://doi.org/10.36090/jh.v8i2.808.

Siregar, Leonardo. "Penerapan Asas Pencemar Membayar Dalam Perkara Perdata Lingkungan Hidup (Studi Putusan Pengadilan Tinggi Riau Nomor 79/Pdt./2014/PTR) .” Jurnal Mercatoria 13, no. 2 (December 28, 2020): 2541-5913. https://doi.org/10.31289/mercatoria.v13i1.3964.

Suhardiman Gumanti, Restu Juniah. "Kajian Implementasi Kegiatan Tanggung Jawab Sosial Perusahaan Pertambangan (Corporate Social Responsibility) Terhadap Pemberdayaan Masyarakat Dan Lingkungan.” Jurnal Empirika 1, no. 2 (November 22, 2016): 111-26. 
https://doi.org/10.47753/JE.V1I2.18.

Suprijadi, Diemas Adhitya Pratama. "KAJIAN HUKUM PEMULIHAN PENCEMARAN LINGKUNGAN DAERAH BEKAS PERTAMBANGAN MENURUT UNDANG-UNDANG NOMOR 32 TAHUN 2009 TENTANG PERLINDUNGAN DAN PENGELOLAAN LINGKUNGAN HIDUP." LEX ET SOCIETATIS. Vol. 7, July 30, 2019. http://pontianak.tribunnews.com/2015/09/10/9-dampak-.

Zam Zam, Zulkifli, and I Made Putrawan. "EVALUASI KEBIJAKAN PENGELOLAAN LINGKUNGAN PERTAMBANGAN DI PULAU OBI PROVINSI MALUKU UTARA.” Jurnal Ilmiah Pendidikan Lingkungan Dan Pembangunan 21, no. 02 (September 29, 2020): 58-68. https://doi.org/10.21009/plpb.212.05.

\section{Regulation}

Law Number 4 of 2009 concerning Mineral and Coal Mining.

Government Regulation No. 78 of 2010 concerning Reclamation and Post-Mining.

Regulation of the Minister of Energy and Mineral Resources Number 18 of 2008. 
